\title{
Colonic Fistula
}

National Cancer Institute

\section{Source}

National Cancer Institute. Colonic Fistula. NCI Thesaurus. Code C78239.

An abnormal communication between the large intestine and another org an or cavity. 